\title{
A duplex real-time RT-PCR assay for detecting H5N1 avian influenza virus and pandemic H1N1 influenza virus
}

\author{
Xiao-ping Kang ${ }^{\dagger}$, Tao Jiang ${ }^{\dagger}$, Yong-qiang Li, Fang Lin, Hong Liu, Guo-hui Chang, Qing-yu Zhu, E-de Qin, Cheng- \\ feng Qin and Yin-hui Yang*
}

\begin{abstract}
A duplex real-time reverse transcriptase polymerase chain reaction (RT-PCR) assay was improved for simultaneous detection of highly pathogenic H5N1 avian influenza virus and pandemic H1N1 (2009) influenza virus, which is suitable for early diagnosis of influenza-like patients and for epidemiological surveillance. The sensitivity of this duplex real-time RT-PCR assay was $0.02 \mathrm{TCID}_{50}\left(50 \%\right.$ tissue culture infective dose) for $\mathrm{H} 5 \mathrm{~N} 1$ and $0.2 \mathrm{TCID}_{50}$ for the pandemic $\mathrm{H} 1 \mathrm{~N} 1$, which was the same as that of each single-target RT-PCR for pandemic $\mathrm{H} 1 \mathrm{~N} 1$ and even more sensitive for H5N1 with the same primers and probes. No cross reactivity of detecting other subtype influenza viruses or respiratory tract viruses was observed. Two hundred and thirty-six clinical specimens were tested by comparing with single real-time RT-PCR and result from the duplex assay was 100\% consistent with the results of single real-time RT-PCR and sequence analysis.
\end{abstract}

\section{Findings}

In March and April 2009, a novel swine-origin pandemic H1N1 influenza virus appeared and spread worldwide. The pandemic of H1N1 2009 influenza virus poses a public health threat. According to the World Health Organization (WHO), as of 30 April 2010, worldwide at least 17919 death cases have been reported [1]. Compared with influenza A H1N1 virus, the highly pathogenic avian influenza virus $\mathrm{H} 5 \mathrm{~N} 1$ has a much higher mortality rate: H5N1 has a mortality rate of more than $50 \%$ while novel pandemic H1N1 has only about 1\% [2]. Nevertheless, pandemic $\mathrm{H} 1 \mathrm{~N} 1$ and highly pathogenic $\mathrm{H} 5 \mathrm{~N} 1$ manifest similar clinical symptoms at the early stage of infection [3]. Early detection of these two pathogens is an essential prerequisite for effective control and prevention of the pandemic.

Real-time RT-PCR/PCR is a powerful method for the sensitive and specific detection of virus-derived nucleic acids in clinical samples [4]. It is time-saving and more specific compared with endpoint PCR. Therefore, realtime RT-PCR assay has been widely used and recom-

\footnotetext{
* Correspondence: yangyinhui@hotmail.com

1 State Key Laboratory of Pathogen and Biosecurity, Beijing Institute of

Microbiology and Epidemiology, Beijing 100071, China

+ Contributed equally

Full list of author information is available at the end of the article
}

mended by WHO for many rapid viral pathogen detection. Moreover, multiplex assays allow to measure several fluorophores in one well, which can simultaneously detect different target sequences [5]. Since the outbreak of pandemic H1N1 influenza, many real-time RT-PCR assays have been developed for detecting of the novel H1N1 [6-13]. Some multiplex real-time RT-PCR assays for simultaneous typing (A/B) and subtyping of $\mathrm{H} 1, \mathrm{H} 2$, $\mathrm{H} 3, \mathrm{H} 5, \mathrm{H} 7$ and $\mathrm{H} 9$ of influenza A viruses have also been reported [14-17]. However, no studies were reported for subtyping of the novel pandemic H1N1 and H5N1 simultaneously.

In this study, a duplex TaqMan real-time RT-PCR assay was improved by adjusting the concentrations of primers and probes in the WHO protocols. The assay could simultaneously detect $\mathrm{H} 5 \mathrm{~N} 1$ avian influenza virus and pandemic H1N1 influenza virus, which could be used for early diagnosis of influenza-like patients and for epidemiological surveillance.

The primers and probes for the novel pandemic H1N1 and the influenza $\mathrm{H} 5 \mathrm{~N} 1$ were derived from the protocols recommended by WHO $[18,19]$. The sequence of primers for H5N1 were H5-sense: 5'-GGA ACT TAC CAA ATA CTG TCA ATT TAT TCA-3', H5-antisense: 5'-CCA TAA AGA TAG ACC AGC TAC CAT GA-3' and H5-probe: 5'- 
HEX-TTG CCA GTG CTA GGG AAC TCG CCA CBHQ1-3' which was labeled with the reporter hexachloro-6-carboxyfluorescein (HEX) at the 5 ' end and a black hole quencher (BHQ1) at the 3' end [19]. The sequence of primers and probe for pandemic $\mathrm{H} 1 \mathrm{~N} 1$ were H1-sense: 5'-GTG CTA TAA ACA CCA GCC TYC CA3', H1-antisense: 5'-CGG GAT ATT CCT TAA TCC TGT RGC-3', H1-probe: 5'-FAM-CAG AAT ATA CAT* CCR GTC ACA ATT GGA RAA-3' which was labeled with the reporter 6-carboxyfluorescein (6-FAM) at the 5 ' end and a black hole quencher (BHQ1) at the a modified T residue [18]. All primers and probes were synthesized by Dalian Takara Company.

RNA was extracted from the supernatants of cultured viruses or from clinical specimens by RNeasy Mini kit (Qiagen, Hilden, Germany) according to the manufacture's instruction. Virus RNA extractions were conducted in Biosafety Level 3 (BSL-3) facilities.

The duplex real-time RT-PCR amplification was carried out in a $20 \mu \mathrm{L}$ volume reaction with the Quantitect Probe RT-PCR kit (Qiagen, Hilden, Germany) with the LightCycler 2.0 system (Roche, Mannheim, Germany). Different concentrations of the primers and probes for both $\mathrm{H} 5 \mathrm{~N} 1$ and $\mathrm{H} 1 \mathrm{~N} 1$ were combined and adjusted to improve the sensitivity of the assay [20]. The concentrations of primers and probe for $\mathrm{H} 5$ gene in the duplex system was optimized by using a serial of 10 -fold diluted H5N1 RNAs as templates. The sensitivity of the duplex assays was evaluated at the concentration of $\mathrm{H} 5$ primers as $0.4 \mu \mathrm{M}, 0.8 \mu \mathrm{M}, 1.6 \mu \mathrm{M}$ and $3.2 \mu \mathrm{M}$. The results showed that the sensitivity of the duplex assays dramatically increased with the concentration of $\mathrm{H} 5$ primers. The duplex assay had the best detecting result at the $\mathrm{H} 5$ primer concentration of $1.6 \mu \mathrm{M}$. The concentration of probes for $\mathrm{H} 5$ gene was also optimized by examining the concentration at $0.1 \mu \mathrm{M}, 0.2 \mu \mathrm{M}, 0.4 \mu \mathrm{M}$ and $0.8 \mu \mathrm{M}$, and any significant different results at different concentrations was not observed. Therefore, $0.1 \mu \mathrm{M}$ was selected as the final concentration of $\mathrm{H} 5$ probe in the duplex realtime RT-PCR system. Similar to the duplex assay for H5 gene, the concentrations of primers and probe for $\mathrm{H} 1$ also were optimized by using RNA from 2, 0.2, 0.02 and 0.002 $\mathrm{TCID}_{50} \mathrm{H} 1 \mathrm{~N} 1$ as templates. The concentration of $\mathrm{H} 1$ primers was optimized from $0.1 \mu \mathrm{M}, 0.2 \mu \mathrm{M}, 0.4 \mu \mathrm{M}, 0.8$ $\mu \mathrm{M}$ and $1.6 \mu \mathrm{M}$, while the concentration of $\mathrm{H} 1$ probe was optimized at $0.1 \mu \mathrm{M}, 0.2 \mu \mathrm{M}, 0.4 \mu \mathrm{M}$ and $0.8 \mu \mathrm{M}$. Thus, $0.4 \mu \mathrm{M}$ of primers and $0.2 \mu \mathrm{M}$ of probe were selected as the optimal concentration for $\mathrm{H} 1$ gene. The reactions were incubated at $50^{\circ} \mathrm{C}$ for $30 \mathrm{~min}$, followed by $95^{\circ} \mathrm{C}$ for $10 \mathrm{~min}, 45$ cycles of $95^{\circ} \mathrm{C}$ for $15 \mathrm{~s}$, and $52^{\circ} \mathrm{C}$ for $1 \mathrm{~min}$. Fluorescence was recorded at $52^{\circ} \mathrm{C}$.

The final optimized reaction mixture consisted of $10 \mu \mathrm{L}$ of $2 \times$ reaction buffer, $0.2 \mu \mathrm{L}$ reverse transcription enzyme, $1.6 \mu \mathrm{M}$ of each $\mathrm{H} 5 \mathrm{~N} 1$ primer, $400 \mathrm{nM}$ of each novel H1N1 primer, $100 \mathrm{nM}$ of $\mathrm{H} 5 \mathrm{~N} 1$ probe, $200 \mathrm{nM}$ of pandemic $\mathrm{H} 1 \mathrm{~N} 1$ probe and $2 \mu \mathrm{L}$ RNA templates. The protocol of real-time RT-PCR for influenza A (H1N1) recommended by WHO used a concentration of $1000 \mathrm{nM}$ each of novel SW H1 primers and $250 \mathrm{nM}$ of SW H1 probe [18]. The WHO real-time RT-PCR protocol for $\mathrm{H} 5 \mathrm{~N} 1$ used a concentration of $800 \mathrm{nM}$ each of $\mathrm{H} 5$ primers and $200 \mathrm{nM}$ of $\mathrm{H} 5$ probe [19].

The sensitivity of the single and duplex real-time RTPCR for novel H1N1 and H5N1 virus was evaluated by 10-fold diluted virus RNA, respectively. The pandemic H1N1 influenza virus strain A/Beijing/501/2009(H1N1) (GenBank: GQ223408-GQ223415) and avian influenza virus H5N1 strain A/Beijing/01/2003 (GenBank: EF587274-EF587281) were cultured on MDCK cells and tested by the assay. The analysis of threshold cycles (Ct) signals as a function of $\log 10 \mathrm{TCID}_{50}$ titers of tested viruses showed a nearly linear decrease of $\mathrm{Ct}$ value with increased virus titer. The sensitivity of the single realtime RT-PCR assay was 0.2 TCID $_{50}$ for both novel pandemic $\mathrm{H} 1 \mathrm{~N} 1$ and $\mathrm{H} 5 \mathrm{~N} 1$ virus. The detection threshold of the duplex real-time RT-PCR assay was $0.2 \mathrm{TCID}_{50}$ for the pandemic $\mathrm{H} 1 \mathrm{~N} 1$ and $0.02 \mathrm{TCID}_{50}$ for $\mathrm{H} 5 \mathrm{~N} 1$ virus. Compared with single real-time RT-PCR assay, the duplex real-time RT-PCR assay had the same sensitivity for pandemic H1N1 virus, and about 10-fold more sensitive for $\mathrm{H} 5 \mathrm{~N} 1$ virus $\left(0.02 \mathrm{TCID}_{50}\right)$ (Figure 1). This was likely because the procedure of the duplex assay for $\mathrm{H} 5 \mathrm{~N} 1$ was optimized for Roche LightCycler 2.0 system, while the single real-time RT-PCR assay recommended by WHO was optimized for ABI instruments [18].

The specificity of the duplex real time RT-PCR assay was validated by using human genomes and a panel of respiratory tract viruses including human seasonal H3N2 influenza viruses, seasonal H1N1 virus, human respiratory syncytial virus A and B, human coronavirus 229E, human coronavirus OC43, influenza B virus, human parainfluenza virus and human adenovirus. All samples were tested negative (data not shown).

A total of 236 clinical throat swab specimens from suspected cases of novel pandemic H1N1 patients were collected. The samples were first detected by WHO realtime RT-PCR protocol for influenza A (H1N1). As the WHO protocol also included a set of primers for universal detection of type A influenza viruses, thus, only the 182 Influenza A positive samples confirmed by WHO protocol were further tested by the duplex system for comparison with the results of WHO protocol. Among the 182 influenza type A positive specimens, 124 specimens were positive for the pandemic H1N1 and none for the H5N1 tested by the duplex system. Duplex real-time RT-PCR assays showed $100 \%$ coincident results with the single real-time assays. Sequence analysis was also con- 

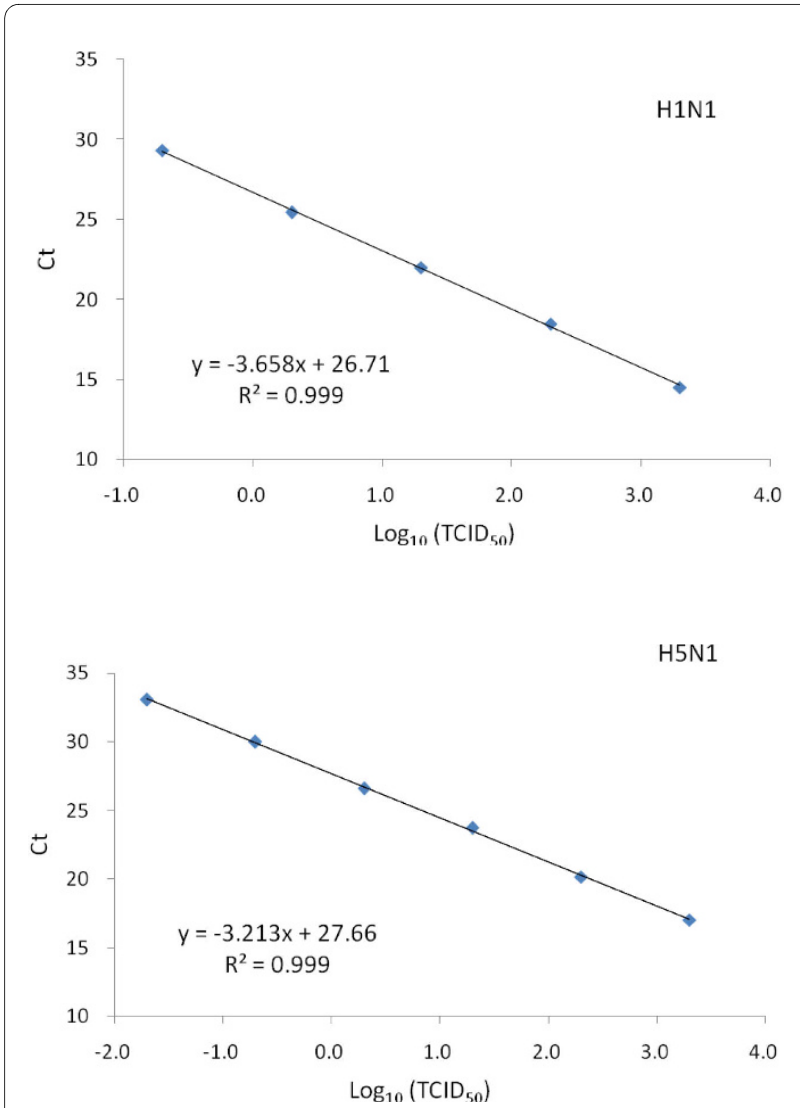

Figure 1 Sensitivity and dynamic range of the duplex real-time RT-PCR assay for detection of $\mathrm{H} 5 \mathrm{~N} 1$ and pandemic $\mathrm{H} 1 \mathrm{~N} 1$ viral RNA. Serial 10-fold dilutions of viral RNA standard (from $2 \times 10^{-2}$ to $2 \times$ $\left.10^{4} \mathrm{TCID}_{50}\right)$ were plotted against the threshold cycle $(\mathrm{Ct})$. A Minimum of $0.2 \mathrm{TCID}_{50} \mathrm{H} 1 \mathrm{~N} 1$ viruses or $0.02 \mathrm{TCID}_{50} \mathrm{H} 5 \mathrm{~N} 1$ viruses per reaction could be detected. The coefficient of determination $\left(R^{2}\right)$ and the equation of the regression curve (y) calculated.

ducted with 20 samples selected randomly from the novel H1N1 positive specimens.

Since few clinical specimens was available currently in China, a mock clinical H5N1 specimen was extracted from the spleen of BALB/C mice infected with high pathogenic $\mathrm{H} 5 \mathrm{~N} 1$ influenza virus to validate the specificity of high pathogenic H5N1 virus. The duplex real-time RT-PCR assay showed strong positive result, which was confirmed by single real-time PCR and subsequent sequencing analyses. This demonstrated that the duplex real-time RT-PCR assay was a substitute method for the current single real-time RT-PCR method.

So far, the number of confirmed severe novel H1N1 cases has reached about seven hundred thousand in China and increased quickly. The lessons from 1918 and 1957 influenza suggested that the pandemic might return in a much more lethal form in the second wave [21]. Recently, the increasing geographic distribution of high pathogenic $\mathrm{H} 5 \mathrm{~N} 1$ as well as its ability to transfer to humans and to cause severe infection has raised serious concerns regarding the control measures of this virus. The duplex real-time RT-PCR assay for pandemic H1N1 and high pathogenic $\mathrm{H} 5 \mathrm{~N} 1$ would play an important role for control and prevention of pandemic caused by these viruses.

\section{Competing interests}

The authors declare that they have no competing interests.

\section{Authors' contributions}

XK and TJ: designed the study, did laboratory testing, analysed the test results, co-wrote and edited the manuscript. YL, FL, LH and GC took samples and did laboratory testing. QZ, CQ and YY organized the overall project and helped edit the manuscript. All authors have read and approved the final manuscript.

\section{Acknowledgements}

This work was supported in part by the National 973 project of China (2010CB534002), and the Major Special Program of National Science and Technology of China (2008ZX10004-401 and 2009ZX10004-204).

\section{Author Details}

State Key Laboratory of Pathogen and Biosecurity, Beijing Institute of Microbiology and Epidemiology, Beijing 100071, China

Received: 9 April 2010 Accepted: 2 June 2010

Published: 2 June 2010

\section{References}

1. WHO: Pandemic (H1N1) 2009-Update 98. 2010.

2. WHO: Cumulative Number of Confirmed Human Cases of Avian Influenza A/(H5N1) Reported to WHO. 2010.

3. Rumschlag-Booms E, Guo Y, Wang J, Caffrey M, Rong L: Comparative analysis between a low pathogenic and a high pathogenic influenza H5 hemagglutinin in cell entry. Virol J 2009, 6:76-81.

4. Mackay IM, Arden KE, Nitsche A: Real-time PCR in virology. Nucleic Acids Res 2002, 30:1292-1305.

5. Wittwer $C T$, Herrmann MG, Gundry CN, Elenitoba-Johnson JKS: Real-time multiplex PCR assays. Methods 2001, 25:430-442.

6. Dong H, Zhang Y, Xiong H, Yan A, Ding G, Chen Y, Xie L, Chen J, Zhang G, Hao P, Cong L, Lu Y, Che X, Wang X, Li Y, Yuen KY, Zhao G, Jin W: Detection of human novel influenza $A(\mathrm{H} 1 \mathrm{~N} 1)$ viruses using multifluorescent real-time RT-PCR. Virus Res 2010, 147:85-90.

7. LeBlanc JJ, Li Y, Bastien N, Forward KR, Davidson RJ, Hatchette TF: Switching gears for an influenza pandemic: validation of a duplex reverse transcriptase PCR assay for simultaneous detection and confirmatory identification of pandemic (H1N1) 2009 influenza virus. JClin Microbiol 2009, 47:3805-3813

8. Jiang T, Kang X, Deng Y, Zhao H, Li X, Yu X, Yu M, Qin E, Zhu Q, Yang Y, Qin C: Development of a real-time RT-PCR assay for a novel influenza $A$ (H1N1) virus. J Virol Method 2010, 163:470-473.

9. Panning M, Eickmann M, Landt O, Monazahian M, Olschläger S, Baumgarte S, Reischl U, Wenzel JJ, Niller HH, Günther S, Hollmann B, Huzly D, Drexler JF, Helmer A, Becker S, Matz B, Eis-Hübinger A, Drosten C: Detection of influenza $A(\mathrm{H} 1 \mathrm{~N} 1)$ virus by real-time RT-PCR. Euro Surveill 2009, 14:19329.

10. Yang JR, Lo J, Liu JL, Lin CH, Ho YL, Chen CJ, Wu HS, Liu MT: Rapid SYBR green I and modified probe real-time reverse transcription-PCR assays identify influenza $\mathrm{H} 1 \mathrm{~N} 1$ viruses and distinguish between pandemic and seasonal strains. J Clin Microbiol 2009, 47:3714-1716.

11. Wang R, Sheng ZM, Taubenberger JK: Detection of novel (swine origin) H1N1 influenza A virus by quantitative real-time reverse transcriptionPCR. J Clin Microbiol 2009, 47:2675-2677.

12. Lau SK, Chan KH, Yip CC, Ng TK, Tsang OT, Woo PC, Yuen KY: Confirmation of the first Hong Kong case of human infection by novel swine origin influenza $A(\mathrm{H} 1 \mathrm{~N} 1)$ virus diagnosed using ultrarapid, real-time reverse transcriptase PCR. J Clin Microbiol 2009, 47:2344-2346.

13. Lorusso A, Faaberg KS, Killian ML, Koster L, Vincent AL: One-step real-time RT-PCR for pandemic influenza A virus (H1N1) 2009 matrix gene detection in swine samples. J Virol Methods 2010, 164:83-87. 
14. Wang W, Ren P, Mardi S, Hou L, Tsai C, Chan KH, Cheng P, Sheng J, Buchy P, Sun B, Toyoda T, Lim W, Peiris JS, Zhou P, Deubel V: Design of multiplexed detection assays for identification of avian influenza a virus subtypes pathogenic to humans by SmartCycler real-time reverse transcription-PCR. J Clin Microbiol 2009, 47:86-92.

15. Suwannakarn K, Payungporn S, Chieochansin T, Samransamruajkit R, Amonsin A, Songserm T, Chaisingh A, Chamnanpood P, Chutinimitkul S, Theamboonlers A, Poovorawan Y: Typing (A/B) and subtyping (H1/H3/ $\mathrm{H} 5$ ) of influenza A viruses by multiplex real-time RT-PCR assays. J Virol Methods 2008, 152:25-31.

16. Wu C, Cheng X, He J, Lv X, Wang J, Deng R, Long Q, Wang X: A multiplex real-time RT-PCR for detection and identification of influenza virus types A and B and subtypes H5 and N1. J Virol Methods 2008, 148:81-88.

17. Li PQ, Zhang J, Muller CP, Chen JX, Yang ZF, Zhang R, Li J, He YS:

Development of a multiplex real-time polymerase chain reaction for the detection of influenza virus type $\mathrm{A}$ including $\mathrm{H} 5$ and $\mathrm{H} 9$ subtypes. Diagn Microbiol Infect Dis 2008, 61:192-197.

18. WHO: CDC protocol of realtime RTPCR for swine influenza $A(\mathrm{H} 1 \mathrm{~N} 1)$. 2009.

19. WHO: Recommendations and laboratory procedures for detection of avian influenza $A(\mathrm{H} 5 \mathrm{~N} 1)$ virus in specimens from suspected human cases. 2007.

20. Hull R, Nattanmai S, Kramer LD, Bernard KA, Tavakoli NP: A duplex realtime reverse transcriptase polymerase chain reaction assay for the detection of St. Louis encephalitis and eastern equine encephalitis viruses. Diagn Microbiol Infect Dis 2008, 62:272-279.

21. Taubenberger JK, Morens DM: 1918 Influenza: the mother of all pandemics. Emerg Infect Dis 2006, 12:15-22.

doi: 10.1186/1743-422X-7-113

Cite this article as: Kang et al., A duplex real-time RT-PCR assay for detecting H5N1 avian influenza virus and pandemic H1N1 influenza virus Virology Journal 2010, 7:113

Submit your next manuscript to BioMed Centra and take full advantage of:

- Convenient online submission

- Thorough peer review

- No space constraints or color figure charges

- Immediate publication on acceptance

- Inclusion in PubMed, CAS, Scopus and Google Scholar

- Research which is freely available for redistribution

Submit your manuscript at www.biomedcentral.com/submit
C) BioMed Central 